\title{
ЦИВІЛЬНО-ПРАВОВИЙ ЗАХИСТ ПРАВ НА ЗАСОБИ ІНДИВІДУАЛІЗАЦЇ̈: ПОНЯТТЯ І СПОСОБИ
}

\author{
ПЕКАР Анастасія Олексї̈вна - здобувач Науково-дослідного інституту \\ інтелектуальної власності НАПрН України Адвокатське об'єднання «Юридична \\ фірма «Онопенко та партнери»
}

DOI 10.32782/EP.2021.26

У статті представлено аналіз поняття $i$ способи ицивільно - правового захисту прав на засоби індивідуалізаийі.

Проведене дослідження дало підстави виділити спільні риси заходів відповідальності $i$ заходів захисту: спрямовані за своӥм впливом на правопорушника; мають на меті захист прав та інтересів потерпілого; можуть бути реалізовані як в добровільному порядку, так і примусовому; прямо закріплені в законодавстві; мають ретроспективний характер; можуть використовуватися як поодиниі, так $i$ у сукупності. Відмінні риси також наявні. Визначено наступні критерї: периим критерієм є наявність при ичивільно-правовій відповідальності позаеквівалентних майнових позбавлень; другий критерій: незмінюваність заходів захисту $i$ змінюваність заходів відповідальності; третій критерієм $є$ часовий (темпоральний) критерій; четвертим критерієм для розмежування заходів відповідальності $i$ заходів захисту є форми їх реалізациї.

Отже, проведене дослідження дає підстави виділити спільні риси заходів відповідальності $i$ заходів захисту: спрямовані за свойм впливом на правопорушника; манть на меті захист прав та інтересів потерпілого.

Ключові слова: ицвільно-правовий захист прав, засоби індивідуалізащї, інтелектуальна власність, недобросовісна конкурениія, заходи відповідальності i захисту.

Актуальність дослідження

Розвиток світової економіки та міжнародної торгівлі в умовах постійно зростаючої конкуренції, поява нових технологій і глобалізація сприяє тому, що спеціальні позначення, які індивідуалізують певного виробника та результати його діяльності набувають есе більшого значення і їх роль зростає.

Правовий режим та сутність засобів індивідуалізації у межах наукового дослідження та у законодавстві є не збалансованим. Еже протягом тривалого часу використання окремих розрізняльних позначень є предметом нормативного впорядкування та наукового дослідження. Негативним, на нашу думку, є те, що для правової охорони комерційного найменування не має спеціального законодавства. Для того щоб визначити його правову охорону потрібно дослідити окремі положення ЦК України, ГК України, Закон України «Про охорону прав на знаки для товарів і послуг», Закон України «Про захист від недобросовісної конкуренції», інші законодавчі акти та практику суду. Застосування судової практики при вирішенні спорів 3 охорони прав на комерційне найменування говорить про те, що існує низка питань, вирішення яких законодавством не передбачено.

Дослідженням даного питання займались такі вітчизняні науковці: Г.О. Андрощук, Ю.А. Бошицький, Т.С. Демченко, О.Ф. Дорошенко, О.Ю. Кашинцева, А.О. Кодинець, В. М. Крижна, Н. А. Іваницька, Н.М. Мироненко, О.П. Орлюк, О.А. Підопригора, О.О. Підопригора та інші. 


\section{Цивільне, підприсмницьке, господарське та трудове право}

Мета статті - аналіз цивільно - правового захисту прав на засоби індивідуалізації: поняття і способи.

\section{Аналіз останніх досліджень і публікацій}

Умови надання правової охорони торговельній марці, комерційному найменуванню, географічному зазначенню передбачені низкою нормативно-правових документів, серед них Цивільний кодекс України, Господарський кодекс України та інші нормативно-правові акти.

Для регулювання реєстрації, правової охорони торговельної марки та географічного зазначення існують спеціальні закони: Закон України «Про охорону прав на знаки для товарів і послуг» 1993 р., Закон України «Про правову охорону географічних зазначень» 2019 р. Однак, і вони потребують вдосконалення, для того, щоб відповідати сьогоднішнім потребам захисту прав на засоби індивідуалізації учасників цивільного обігу, товарів і послуг та відповідати стандартам передбаченими міжнародно-правовими документами та законодавству EC.

За визначенням науковців, нормативні положення щодо регулювання інтелектуальної власності мають сприяти ефективнішому руху у процесі визнання України в Европейському Союзі [10; с. 119]

Тому ми вважаємо за потрібне врегулювання термінологічної різноманітності засобів індивідуалізації учасників цивільного обігу, товарів і послуг. Зокрема, ст. 420 ЦК України передбачає, що до об'єктів інтелектуальної власності належать торговельні марки, комерційні найменування та географічні зазначення.

16.08.2020 набув чинності Закон України № 815-IX від 21.07.2020 р. «Про внесення змін до деяких законодавчих актів України щодо посилення охорони і захисту прав на торговельні марки і промислові зразки та боротьби з патентними зловживаннями», відповідно до якого дефініцію «знак» як позначення, за яким товари і послуги одних осіб відрізняються від товарів і послуг інших осіб, замінено на термін «торговельна марка», таким чином було гармонізовано визначення цього терміна в главі 44 ст. 492-500
ЦК України, главі 16, ст. 157, 158 ГК України та Законі України «Про охорону прав на знаки для товарів і послуг» від 15 грудня 1993 року.

Стосовно комерційного найменування, то законодавство оперує, знову ж таки, кількома позначеннями - «комерційне найменування», «фірмове найменування», «комерційне (фірмове) найменування».

Щодо географічного зазначення, правова охорона надається на підставі їх реєстрації у встановленому Законом України «Про правову охорону географічних зазначень» порядку або відповідно до міжнародних договорів України та діє безстроково, за винятком випадків, визначених цим же законом.

Обсяг правової охорони географічного зазначення визначається характеристиками товару і межами географічного місця його походження, зазначеними у Реєстрі. ${ }^{1}$.

При цьому п. 3 ст. 1 Закону України «Про правову охорону географічних зазначень» визначено, що географічне зазначення - найменування місця, що ідентифікує товар, який походить 3 певного географічного місця та має особливу якість, репутацію чи інші характеристики, зумовлені головним чином цим географічним місцем походження, і хоча 6 один з етапів виробництва якого (виготовлення (видобування) та/або переробка, та/або приготування) здійснюється на визначеній географічній території.

Незаконне використання географічного зазначення - це його використання особами, які не мають відповідного свідоцтва, навіть якщо при цьому вказується справжнє місце походження товару або найменування використовується у перекладі або в поєднанні 3 такими словами, як «рід», «тип», «імітація» і тому подібними, а також використання подібного позначення для будь-яких товарів, які здатні ввести споживачів в оману щодо місця походження та особливих властивостей товару.

Правовий режим такого засобу індивідуалізації, як доменне ім'я, поки що ще взагалі не отримав законодавчого закріплення. Icнують різні думки з приводу того, чи є до-

\footnotetext{
1 Закон України «Про правову охорону географіч-
} них зазначень» 
менне ім'я засобом індивідуалізації чи ні, однак ми вважаємо за потрібне врегулювати правову охорону цього об'єкта.

Адже слід враховувати, що доменне ім'я, в певних випадках, може трансформуватися в позначення, що виконує функції торговельної марки, формально до неї не відносячись, і в такій ситуації в рамках конкретного спірного правовідношення, доменне ім'я можна віднести до такого об'єкта інтелектуальної власності, як торговельна марка.

Щодо умов надання правової охорони, то в цьому випадку теж виникає багато питань. По-перше, щодо прав попереднього користувача на торговельну марку. ЦК України не передбачає: можливість захисту попереднім користувачам торговельної марки від неправомірного використання третіми особами, умови набуття права попереднього користувача у випадку, коли торгівельна марка буде визнана добре відомою, оцінних критеріїв для набуття права попереднього користувача - законодавством встановлено лише загальні засади. На нашу думку, така недосконалість є значним недоліком і потребує врегулювання. По-друге, для захисту прав на комерційне найменування велике значення має питання його структури. Питання визначення складу комерційного найменування віднесено до компетенції суду та має вирішуватись ним відповідно до чинного законодавства і на підставі наявних у справі доказів. Однак, стає незрозумілим, на підставі якого закону та на підставі яких доказів, якщо не існує спеціального закону щодо комерційного найменування.

По-третє, у 2019 році набув чинності Закон України «Про правову охорону географічних зазначень», до цього часу діяв Закон України «Про охорону прав на зазначення походження товару», створено відповідний державний реєстр, однак варто зауважити, що за час, протягом якого створили національну систему з охорони географічних зазначень, кількість таких зареєстрованих позначень є незначною.

До відома, в Україні станом на 1 червня 2019 р. зареєстровано 3115 географічних зазначень. Більшість із цих географічних зазначень належить європейським виробникам і охороняється на території України на виконання Угоди про асоціацію з EC. Згідно з національною процедурою в Україні зареєстровано лише 42 кваліфіковані зазначення походження товарів (КЗПТ) та видано лише 34 свідоцтва на право використання зареєстрованих КЗПТ. Протягом 2014-2018 років подавалося 3 - 4 заявки на реєстрацію КЗПТ у рік. Тобто в Україні зареєстровано лише 14 КЗПТ стосовно українських виробників. При цьому 6 з них («Сонячна долина», «Новий світ», «Золота балка», «Балаклава», «Меганом» та «Магарач») зареєстровані стосовно виробників десертних марочних вин, вин, вин ігристих, що розташовані на території АР Крим. У зв'язку з анексію АР Крим такі КЗПТ не можуть використовуватись українськими виробниками.

Упродовж 2019-2020 років Міністерством розвитку економки, торгівлі та сільського господарства України видано свідоцтва про реєстрацію права про використання зареєстрованого зазначення походження товару - сир «Гуцульська овеча бриндза», «Гуцульська коров’яча бриндза», «мелітопольська черешня».

У рамках роботи проєкту $\mathrm{EC}$ «Географічні зазначення в Україні» Мінагрополітики вибрані українські продукти з географічними зазначеннями, які планується зареєструвати (наведено робочі назви): «Шабській», «Ялпуг», «Закарпаття» та «Білгород-Дністровський» щодо вина, «Карпатський мед» щодо меду .

У сучасному світі питання уніфікації правового регулювання захисту засобів індивідуалізації мають першорядне значення в контексті стабільного ефективного розвитку виробничо-торгового потенціалу як окремих держав, так і їх об'єднань у рамках універсальних та регіональних міжнародних організацій. Проблеми охорони результатів інтелектуальної діяльності, що виражаються в тих чи інших об'єктах промислової власності та прирівняних до них у контексті термінології українського законодавства засобів індивідуалізації, є предметом обговорення науковців різних держав 3 давніх часів [1; c. 24].

3 метою залучення споживачів, підприємці використовують численні засоби інди- 


\section{Цивільне, підприсмницьке, господарське та трудове право}

відуалізації, останні набувають велике економічне значення. Засоби індивідуалізації визначають взаємозв’ язок між виробниками і споживачами продукції і інформують покупців про конкретного виробника, який маркує продукцію, іï якості, основні характеристики та місце походження. Саме тому, необхідно досліджувати внутрішню структуру цивільно-правового захисту інтелектуальної власності як правового явища. Кращим способом вирішення цього завдання є побудова науково-гносеологічної моделі механізму іiі здійснення та аналіз складових елементів даного механізму [10; с. 120].

При цьому ми пропонуємо авторське розуміння механізму цивільно-правового захисту інтелектуальної власності, під яким розуміємо певне поєднання елементів, що складають його структуру і дають в кінцевому рахунку уповноваженій особі в разі порушення належних йому прав інтелектуальної власності реальну можливість вдатися до тих чи інших способів захисту.

Як вказується в літературі, реалізація права на захист завжди здійснюється в певному порядку, використання якого рівнозначно застосуванню належної форми, засобів і способів захисту.

Відповідно, на основі норм українського законодавства прийнято виділяти юрисдикційну форму захисту прав інтелектуальної власності, пов'язану з діяльністю уповноважених органів. Щодо захисту порушених чи оскаржених прав, і неюрисдикційну форму захисту - самостійно здійснювані дії громадян і організацій щодо захисту своїх прав i охоронюваних законом інтересів (які, природно, треба відмежовувати від самоврядних дій) [2; с. 37].

Ця точка зору підтверджується положеннями, виробленими наукою цивільного процесуального права, 3 якого випливає, що спосіб захисту права - категорія матеріального права, у той час, як форма захисту права - категорія процесуального характеру, під якою слід розуміти діяльність компетентних органів, що має свою законодавчу регламентацію і спрямована на захист прав за допомогою властивих їй методів, які залежать від правової природи відповідного юрисдикційного органу. Такими методами можна вважати визначення даних про факти, використання щодо таких даних відповідних правових норм, за допомогою чого визначається необхідних спосіб захисту прав, прийняття процесуального рішення і контроль за їх виконанням. Задля застосування конкретного способу захисту, що передбачений в законі, необхідно використати декілька форм захисту щодо порушеного права [7; с. 5].

Юрисдикційна форма захисту інтелектуальної власності здійснюеться, в першу чергу, у судовому порядку, який є одним 3 найважливіших елементів цивільно-правового захисту будь-яких цивільних прав, у тому числі і прав інтелектуальної власності, а також в адміністративному порядку.

У чинних в Україні нормативно-правових актах, що регулюють питання інтелектуальної власності, вказані різні способи захисту прав на ті чи інші об'єкти інтелектуальної власності.

Численність матеріально-примусових заходів, передбачених цивільним законодавством України і застосовуваних при захисті інтелектуальної власності, а також їх неоднорідність за своєю природою, роблять необхідним їх класифікацію.

Найбільш поширеним і досить глибоко обгрунтованим у цивілістиці $є$ поділ способів захисту на заходи захисту та заходи відповідальності, які мають такі критерії, як підстави застосування, соціальне спрямування, виконувані функції, принципи реалізації тощо. По відношенню до заходів відповідальності та заходів захисту в літературі з загальної теорії права також використовуються терміни «правововідновлювальні санкції» і «штрафні санкції» [3].

Продовжуючи аналіз зазначеної проблеми, звернемо увагу, що заходи відповідальності, як і заходи захисту, мають спільні риси: спрямовані за своїм впливом на правопорушника; мають на меті захист прав та інтересів потерпілого; можуть бути реалізовані як в добровільному порядку, так і примусовому; прямо закріплені в законодавстві; мають ретроспективний характер; можуть використовуватися як поодинці, так і у сукупності. 
Наведення спільних рис заходів відповідальності і заходів захисту наштовхує на думку щодо відмінних рис, які є не менш істотними. Так, першим критерієм є наявність при цивільно-правовій відповідальності позаеквівалентних майнових позбавлень [12; с. 80]. Використовуючи цей критерій, пропонується розмежовувати заходи захисту і заходи відповідальності за способами, які вони використовують. Так, до способів захисту слід відносити відновлення становища, що передувало правопорушенню; зупинення протиправних дій; визнання порушеного права. Такі заходи представляють собою один $з$ способів захисту права [11;c. 288]

Другим критерієм для визначення відмінностей заходів відповідальності і заходів захисту, на нашу думку, слід вважати такий: незмінюваність заходів захисту і змінюваність заходів відповідальності. Так, порушене право може бути захищено тільки прямо визначеним способом захисту. Водночас, заходи відповідальності можуть бути застосовані на розсуд правомочних осіб або органів. Заходи відповідальності можуть бути замінені іншими заходами відповідальності, що неможливо для заходів захисту.

Третім критерієм слід визнати часовий (темпоральний) критерій. Інакше кажучи, мова йде про визначення процесуальних термінів, протягом яких застосовуються заходи захисту або заходи відповідальності. Так, особливістю заходів захисту $є$ те, що вони застосовуються в терміни, коли суб'єктивне ще існує, але воно було порушено. Неможливо застосувати заходи захисту якщо право зупинило своє існування.У свою чергу, заходи відповідальності можуть бути використані як для відновлення порушеного права, що вже припинило своє існування, так і для відновлення права, що продовжило своє існування, незважаючи на порушення.

Четвертим критерієм для розмежування заходів відповідальності і заходів захисту слід вважати форми їх реалізації. Так, заходи відповідальності можуть реалізовуватися за допомогою грошової або натуральної форми. Способів захисту, які можуть реалізовуватися в грошовій формі, не передбаче- но законодавством (за деякими винятками). Всі ці характеристики переломлюються через особливості інтелектуальної власності і проявляють себе при використанні на практиці конкретних способів захисту [4; с. 188]

Крім поділу способів захисту інтелектуальної власності на заходи захисту та заходи відповідальності, існує ще кілька корисних класифікацій для проведення грунтовного дослідження.

За функціональною спрямованістю способи захисту прав інтелектуальної власності можна класифікувати на відновлювальні, припиняючі і способи, спрямовані на визнання права.

Відновлювальні способи захисту інтелектуальної власності спрямовані на захист виключних прав у тому вигляді, якими вони були до порушення, в чистому вигляді, тобто повернення в статус кво право володільця. Припиняючі заходи захисту інтелектуальної власності - це, наприклад, заборона діяльності, що створює загрозу заподіяння шкоди правовласника в майбутньому тощо. Такі заходи захисту можуть бути застосовані у разі, якщо характер правопорушення є тривалим, що досить характерно для порушень прав інтелектуальної власності. Заходи захисту, спрямовані на визнання права (або факту) - це одні з найбільш часто використовуваних у праві інтелектуальної власності, які спрямовані на визнання факту володіння правом за правовласником [2; c. 45$]$.

Заходи відповідальності за таким критерієм, як функціональна спрямованість, розподіляються на компенсаційні, штрафні та конфіскаційні.

Компенсаційні заходи відповідальності мають свою особливість, яка проявляється в тому, що розмір компенсації визначається розміром завданих збитків потерпілому.

Ринкова економіка сприяла тому, що штрафні заходи відповідальності стали найбільш розповсюдженими. Розмір їх обчис^юється, виходячи з суми боргу, терміна прострочення і величини неустойки (відсотків). Використання таких способів захисту інтелектуальної власності найбільш характерно при договірних правовідносинах правовласника $з$ користувачем. 


\section{Цивільне, підприсмницьке, господарське та трудове право}

Конфіскаційні заходи відповідальності мають своєю особливістю те, що неможливо зменшити розмір відповідальності, а також те, що вони реалізуються в добровільному порядку [6; с. 225]

За методом встановлення способів захисту, які використовуються в області інтелектуальної власності, їх можна розділити на договірні і позадоговірні; а також виділити змішаний вид - комбіновані способи захисту.

Коротко розглянуті вище цивільно-правові способи захисту є ніби статикою механізму захисту прав засобів індивідуалізації. Тим часом, особливості захисту виняткових прав можна виявити тільки при паралельному розгляді цього правового феномена який триває в часі процесу.

Точкою відліку для аналізу такого процесу $є$ «нормальна» ситуація, коли права інтелектуальної власності ще не порушені, ще не оскаржені. Правовласник при реалізації своїх виключних прав на об'єкти інтелектуальної власності перебуває з необмеженим колом третіх осіб у правовідносинах, які можна охарактеризувати як абсолютні. Як вказується в літературі, в абсолютних правовідносинах уповноваженій особі протистоїть невизначене число зобов'язаних осіб. Має місце юридичний зв'язок між визначеним колом суб'єктів, що уповноважені на використання права, тобто правоволодільцями, із невизначеним колом зобов'язаних осіб [5]

Проведений аналіз дозволяє розкрити саме цивільно-правовий аспект порушень прав на засоби індивідуалізації та їх захисту. Природно, що порушення виключних прав може містити в собі склад адміністративного та кримінального правопорушення, що робить можливим застосування правового інструментарію відповідних галузей права [9].

Акти недобросовісної конкуренції у сфері прав на засоби індивідуалізації як юридичні факти-правопорушення передбачають виникнення певних юридичних наслідків, до яких поряд 3 юридичною відповідальністю належить i захист прав добросовісних конкурентів і потенційних споживачів. В умовах сучасної України, коли, як зазначає I. Мойсеєнко, відбувається формування правової системи, що відповідає потребам суспільного розвитку та потреб громадян, вкрай актуальним є питання про захист суб'єктивних прав [9].

Викладений функціональний склад цивільно-правових способів захисту і мір відповідальності найбільшою мірою дозволяе захистити суб'єктивні права господарюючих суб’єктів-конкурентів і споживачів від недобросовісних конкурентних актів [8; с. 21].

\section{Висновок}

Проведене дослідження дає підстави виділити спільні риси заходів відповідальності і заходів захисту: спрямовані за своїм впливом на правопорушника; мають на меті захист прав та інтересів потерпілого; можуть бути реалізовані як у добровільному порядку, так і примусовому; прямо закріплені в законодавстві; мають ретроспективний характер; можуть використовуватися як поодинці, так і у сукупності.

\section{Лiтература}

1. Агамагомедова С. А. Захист прав на зазначене походження товарів при їхтранско рдонномупереміщенні // Патенти і ліцензії. 2011. N 12. C. 24, 25.

2. Андрощук Г., Афян А. Конфлікт між торговельними марками та географічними значеннями: механізми вирішення //Теорія і практика інтелектуальної власності. - 2015. - №. 1. - С. 37-45-37-45.

3. Дмитришин В. С. Розпоряджання майновими правами інтелектуальної власності в Україні: навч. посіб. / В. С. Дмитришин. - К.: Ін-т інтел. власн. і права, 2008. -248 c.

4. Жаров В. О. Інтелектуальна власність в Україні: правовіаспекти набуття, здійснення та захисту прав. - К. :ВидавничийДім “Ін Юpe", 2000. - С. 188.

5. Інтелектуальнавласність у бізнесі: боротьба з тролями та бренд рейдерством // Матеріали семінарупрактикуму «Інтелектуальна власність у підприємницькій діяльності», Аьвів. - 2015 p. [Електронний ресурс]. - Режим доступу: 40 http://vgolos.com.ua/articles/intelektualna_ 
vlasnist_u_biznesi_borotba_z_tr olyamy_ta_ brendreyderstvom_176323.html

6. Кодинец А. А. Договора в сфере интеллектуальной собственности: проблемы правового регулирования / А.А. Кодинец // Альманах цивилистики. - К., 2010. - Вип. 3. - C. 225-252.

7. Крижна В. М. Принцип справедливості, добросовісності та розумності і правові наслідки недійсності договорів у сфері інтелектуальної власності / В. Крижна // Теорія і практика інтелектуальноївласності. - 2008. - № 6. - С. 3-7.

8. Кузнецова Н. С. Проблеми захисту прав на інтелектуальну власність в Україні / Н. С. Кузнецова, О. В. Кохановська // Право України. - 2011. - № 3. - С. 21-29.

9. Мойсеєнко І.П. Управління інтелектуальним потенціалом: монографія. Аьвів: Аверс, 2015. - 304 с

10. Орлюк О. Европейськіорієнтири для національної сфери інтелектуальної власності. Сучасні проблеми порівняльного правознавства: зб. наук. пр. / НАН України, Ін-т держави і права ім. В. М. Корецького [та ін.]. - Ужгород; Київ : Говерла, 2015.C. 119-122.

11. Поліщук В. $\lambda$. Роль нематеріальних активів у формуванні i розвитку конкурентноспроможності суб'єкта господарювання //Вісник Національного університету водного господарства та природокористування. Економічні науки. 2016. - №. 2. - C. 288-296.

12. Степаненко С. Управління торговельними марками: боротьба 3 паразитизмом //Журнал європейської економіки. 2017. - T. 13. - №. 1. - C. 80-93.

Pekar A. O. Applicant at the Research Institute of Intellectual Property of the National Academy of Science of Ukraine Onopenko \& Partners Law Firm 01601, Kyiv, str. Y. Konovalets, 3, of. 29

The article presents an analysis of the concept and methods of civil protection of rights to the means of individualization.
The study provided grounds to identify common features of liability and protection measures: aimed at their impact on the offender; aim to protect the rights and interests of the victim; can be implemented both voluntarily and compulsorily; directly enshrined in law; have a retrospective character; can be used alone or in combination. Distinctive features are also available. The following criteria are defined: the first criterion is the presence of non-equivalent property deprivations in civil liability; the second criterion: invariability of protection measures and variability of liability measures; the third criterion is the temporal (temporal) criterion; the fourth criterion for distinguishing between liability and protection measures are the forms of their implementation.

Thus, the study provides grounds to identify common features of liability and protection measures: aimed at their impact on the offender; aimed at protecting the rights and interests of the victim.

The study provided grounds to identify common features of liability and protection measures: aimed at their impact on the offender; aim to protect the rights and interests of the victim; can be implemented both voluntarily and compulsorily; directly enshrined in law; have a retrospective character; can be used alone or in combination. Distinctive features are also available. The following criteria are defined: the first criterion is the presence of non-equivalent property deprivation in civil liability; the second criterion: invariability of protection measures and variability of liability measures; the third criterion is the temporal (temporal) criterion; the fourth criterion for distinguishing between liability and protection measures are the forms of their implementation.

Thus, the study provides grounds to identify common features of liability and protection measures: aimed at their impact on the offender; aimed at protecting the rights and interests of the victim.

Key words: civil-legal protection of rights, means of individualization, intellectual property, unfair competition, measures of responsibility and protection. 